American Journal of Applied Sciences 8 (5): 420-427, 2011

ISSN 1546-9239

(C) 2010 Science Publications

\title{
Damage Pattern and Nesting Characteristic of Coptotermes curvignathus (Isoptera: Rhinotermitidae) in Oil Palm on Peat
}

\author{
${ }^{1}$ Seow-Phan Chan, ${ }^{1}$ Choon-Fah J. Bong and ${ }^{2}$ Wei-Hong Lau \\ ${ }^{1}$ Department of Crop Science, Faculty of Agriculture and Food Sciences, \\ University Putra Malaysia Bintulu Sarawak Campus, \\ Jalan Nyabau, 97008 Bintulu, Sarawak, Malaysia \\ ${ }^{2}$ Department of Plant Protection, Faculty of Agriculture, \\ University Putra Malaysia, 43400 UPM Serdang, Selangor, Malaysia
}

\begin{abstract}
The oil palm industry of Malaysia has expanded into peat area in Sarawak. Problem statement: The subterranean termite Coptotermes curvignathus was a serious pest of oil palm on peat. Control of this termite has resorted to heavy usage of chemicals which was deemed uneconomical and hostile to the environment. Baiting system has inconsistent success due to the limited knowledge of the behavior of the pest. Approach: This study was to investigate damage and nesting characteristic of the pest. Infested palm in the peat area was dissected using a chainsaw and observation was made on the endoecie and damage. Microclimate inside the palm was recorded using a data logger and acid insoluble lignin from 3 different infested palms was determined. Results: Dissection of infested palm revealed that termite generally attacked the palm from the spear in immature palm or basal region in mature palm due to the energy requirement and level of water table. Spear region infestation was possible because of the moist environment provided by the proximity of the fronds and leaf sheaths. The high lignin content (42-45\%) in the thin laminae indicated the concentration of lignin or incorporation of peat in nest construction. Wood stump residues remained in the plantation was one of the main reasons of termite infestation. The stability and protection of the wood stump encouraged termite breeding. A C. curvignathus queen was discovered in the endoecie under the wood stump and was seen mobile. Conclusion: The pest was generally available in area where wood stumps and moisture were available. Manipulation of water table for certain period after spraying of chemical may help reduce infestation by the termite.
\end{abstract}

Key words: Oil palm, Coptotermes curvignathus, damage pattern, nesting characteristic

\section{INTRODUCTION}

Malaysia is one of the leading producers and exporters of palm oil in the world with 4.69 mil hectares planted with oil palm (MPOB). Suitable land for oil palm planting is rapidly diminishing and moving into peat area is inevitable. The eastern state of Sabah and Sarawak accounted for about $45 \%$ of the total area of oil palm planted in Malaysia. The state of Sarawak possesses 1.67 million ha of peat which provides a good opportunity for further expansion of the oil palm industry. However planting oil palm in peat is challenging as the water table is constantly high, with impending subsidence of the peat, poor anchorage of the palm and insect pest attack. A peat area with a lot of woody material is a natural habitat of the subterranean termite. Most of the termites are beneficial termites such as the scavenger and wood feeder that help in maturing the peat and breaking down of materials that supply nutrients to the crops, while some termites are pests that feed on living plant tissue that may prove a problem to oil palm planters.

Termite is one of the common pests of oil palm planted on peat in Malaysia and Indonesia (Lim and Silek, 2001) Coptotermes curvignathus has been identified as the major palm killer especially the immature palm. It has also been reported to attack Acacia mangium rubber (Hevea brasiliensis) and other fruit trees such as coconut and mango (Khoo et al., 1991) Coptotermes curvignathus is the largest in size and most aggressive among the oriental Coptotermes spp. (Thapa, 1981). It has been noted to damage fresh

Corresponding Author: Choon-Fah J. Bong, Department of Crop Science, Faculty of Agriculture and Food Sciences, University Putra Malaysia Bintulu Campus, Nyabau Road, 97000 Bintulu, Sarawak, Malaysia Tel: 6086-855405 Fax: 6086-855415 
tissue rather than scavenging and feeding on woody material. It is easy to identify as it secretes a milky white liquid from its frontal fontanelle when in defense.

Heavy usage of chemical pesticides has been employed to prevent Coptotermes sp. from spreading which includes drenching and spraying the trunk, crown and shoot. The palm would be sprayed with chemical on a monthly basis since the first day of detection of infestation. Some planters treat an additional 6 palms surrounding the infested palm to prevent the termite from shifting to the nearby palms. The most common pesticide used was chlorpyrifos at $0.16 \%$ a.i. at $0.35-5$ liters mixture per palm which cost about 5.00-RM 7.00 depending on area and location. It was quite effective against Coptotermes sp. but had a residue effect of about 2 months. Other chemicals such as friponil and imidacroprid were also used. Drastic control measures are needed as severe infestation can kill the palm. However the heavy usage of pesticide proves non economical and can be destructive to the environment and other beneficial termite such as the scavenger and wood feeder.

Thus, termite control in plantations has resorted to more environmental friendly and more target specific methods. Baiting system has been widely used nowadays with slow acting toxicant or chitin synthesis inhibitor such as hexaflumuron (Tsunoda et al., 1998; Su et al., 2000) incorporated. Hoe et al. (2009) explored the use of entomopathogenic fungi such as Metarhizium anisopliae var. anisopliae to control Coptotermes curvignathus. The baiting system capitalizes on the feeding behavior of termite, trophallaxis that involves grooming and exchange of secretions or liquid food between individuals (Pearce, 1997). Thus when the pest feeds on the bait, the chemical will be passed on from one to another and in times will gradually reduce the pest population. The success of baiting system rest on the knowledge of the behavior of the respective pest (Su et al., 1991) therefore the investigation of Coptotermes curvignathus's nesting and foraging behavior is important in order to control the pest biologically. Thus, the objective of the study was to determine the factors that may affect the infestation of oil palm and the nesting characteristic of Coptotermes curvignathus in peat.

\section{MATERIALS AND METHODS}

Location of sites: The main study was conducted a 2822 ha oil palm plantation developed on peat approximately $70 \mathrm{~km}$ West of Bintulu, Sarawak. The peat depth ranged from $1 \mathrm{~m}$ to $3 \mathrm{~m}$, while having a mean daily temperature of $26.5^{\circ} \mathrm{C}$, means relative humidity of $83.6 \%$ and receives an average of 6.5 hours of daily sunshine. The total annual rainfall of the area was 5349 $\mathrm{mm}$ in 2009 with the highest rainfall at the beginning and end of the year. Topographically the area is relatively low-lying and flat with an average water table of $40 \mathrm{~cm}$ below the soil surface. Three sites namely Block 16 (N 03 01' 00.6”, E $112^{\circ}$ 52' 51.7”), Block 9 (N 03 00' 47.1”, E $112^{\circ}$ 52' 47.2”) and Block 13 (N $03^{\circ} 01^{\prime} 17.6^{\prime \prime}, \mathrm{E} 112^{\circ} 52^{\prime}$ 59.7”) were selected for the study of Coptotermes curvignathus infestation and damage pattern. The planting blocks covered 39.41 ha, 9.93 ha and 22.01 ha respectively with planting density of $160 \mathrm{palm} \mathrm{ha}^{-1}$. Parallel field drains were constructed at every 4 rows of palm to provide drainage in the area.

Field studies were also carried out at another 3000 ha plantation located about $127 \mathrm{~km}$ West of Bintulu, in Block 1 (N 02 $53^{\prime}$ 41.5”, E 112 38' 40.6”) and Block 6 ( $\mathrm{N} 02^{\circ} 53^{\prime} 41.6^{\prime}$ ', E $112^{\circ} 37^{\prime}$ 55.5”). The palms were planted on deep peat and covered about 31.12 ha in both blocks with planting density of $151 \mathrm{palm} / \mathrm{ha}$ and parallel field drains at every 4 rows of palm. The level of water table was maintained at $70 \mathrm{~cm}$ below soil surface.

Damage pattern and nesting characteristic of Coptotermes curvignathus: Seven termite infested palms were identified and studied. The existing condition of the surrounding infested area was recorded. The similarities among the existing conditions such as the vegetation, age of palm, drainage and presence of wood stumps were identified to determine the factors that may lead to termite infestation.

The study on the damage pattern was done by dissection of severely infested palms using a Stihl 20inch chainsaw and an infested wood stump. The palm was cut cross sectionally followed by longitudinal sectioning to expose the inner part of the palm, while the wood stump was lifted up to examine the damage done. The sectioning of the spear region which consisted of unopened young shot and the inner trunk was also done. The wood stump examined was the leftover tree stump from the previous forest clearing. The differences of how $C$. curvignathus damaged the oil palm and a wood stump were determined and compared by looking at the galleries and chambers construction. The infested oil palm trunk was then further cut into smaller pieces and oven-dried at $60{ }^{\circ} \mathrm{C}$ for 4 weeks in the laboratory for further study.

The microclimate inside the infested palm: The microclimate such as temperature and moisture was recorded via a data logger (HOBO micro station). A hole was made in the basal region and probes were inserted as deep as possible into galleries within the palm before sealing the wound with modeling clay and 
covered the place with fronds to minimize external influence. Surface temperature was also recorded using an infrared temperature probe (MiniTemp MT4, Raytek).

Lignin determination: Thin laminae in the endoecie were collected from 3 different palms for acid insoluble lignin determination. The thin laminae was air dried before subjected to Klason lignin determination method.

\section{RESULTS}

Damage pattern of $C$. curvignathus in oil palm on peat: Two types of termite infestation in oil palm were observed. Coptotermes curvignathus infested a palm either from the spear or the basal region (Table 1). Most of the infestation observed was confined in the spear region where mud sheeting was seen coating the trunk and fronds of the palm. The mud sheeting provides protection from predators and created a moist environment for $C$. curvignathus on the way from the base of the trunk to the spear region. The surface temperature in between the frond axil and its leaf sheath ranged between 26 and $28^{\circ} \mathrm{C}$. The microclimate caused by the proximity of the fronds and the fibrous leaf sheath within the crown together with moist mud offered C. curvignathus an appropriate environment to forage. The symptoms of attack included broken and dried up spear though the palm appeared healthy and sometimes damaged female flower and leaf sheath were also observed. The cross section of the spear revealed C. curvignathus's gallery in the young unopened shoot (Fig. 1). It damaged the cabbage by excavating tunnels, incorporated with carton material which resulted in gallery construction. Further excavation by the termite led to weakening and snapping of the spear. In certain cases, the infestation continued downward towards to the base of the palm with an ovoid cavity $(105 \mathrm{~mm}$ in height and $210 \mathrm{~mm}$ in width) found beneath the cabbage.

Infestation via the basal part of the palm was less obvious initially as there was no mud sheeting on the trunk or the spear region. Symptoms were manifested much later as infestation become severe.

Young immature palms appeared generally weak with yellowing fronds that later dried up killing the palm. In mature palm, the main symptom was snapping of the trunk at about 1-2 $\mathrm{m}$ from the ground surface. Some severely infested palms may topple over due to the weakened basal region.

In basal infestation, C. curvignathus moved through the peat and gained entry into the palm by tunneling through the base of the palm and creating an oblique entry hole measuring $16 \times 67 \mathrm{~mm}$. The termite then consumed the less dense tissue in the central portion of the trunk, creating a huge cavity as they travelled upward towards the meristematic spear region (Fig. 2). The cavity measured abo $500 \mathrm{~mm}$ high and $400 \mathrm{~mm}$ wide, leaving about $100-200 \mathrm{~mm}$ of peripheral fibrous tissue. The cavity appeared to get larger as the termite excavated towards the spear, thereby creating a weak spot that led to snapping of severely infested palm.

Nesting characteristic of $C$. curvignathus in oil palm: As C. curvignathus infested the palm, it built a nest inside the palm or in the spear region depending on the mode of attack. If the attack started at the spear region then C. curvignathus may construct subsidiary nest by covering the oil palm fruit with a mixture of mud and organic material called carton.

\begin{tabular}{ll}
$\begin{array}{l}\text { Table1: Symptoms and mode of attack of Coptotermes curvignathus } \\
\text { Mode of } \\
\text { entry }\end{array}$ & Symptoms \\
\hline $\begin{array}{l}\text { Spear } \\
\text { region }\end{array}$ & $\begin{array}{l}\text { Mud sheeting covering trunks and fronds in the } \\
\text { crown area } \\
\text { Broken and dried up spear, while the palm } \\
\text { appeared healthy } \\
\text { Coptotermes curvignathus could be found } \\
\text { underneath mud sheeting or frond base } \\
\text { and in some cases } \\
\text { secondary nests were found infesting the fruits } \\
\text { Yellowing and weak immature palm } \\
\text { No obvious mud sheeting observed on trunk of } \\
\text { mature palm } \\
\text { Snapped trunk and sometimes fallen palm } \\
\text { Large quantity of mud observed within the } \\
\text { palm in the snapped area } \\
\text { A large cavity was usually found inside the palm }\end{array}$ \\
\end{tabular}

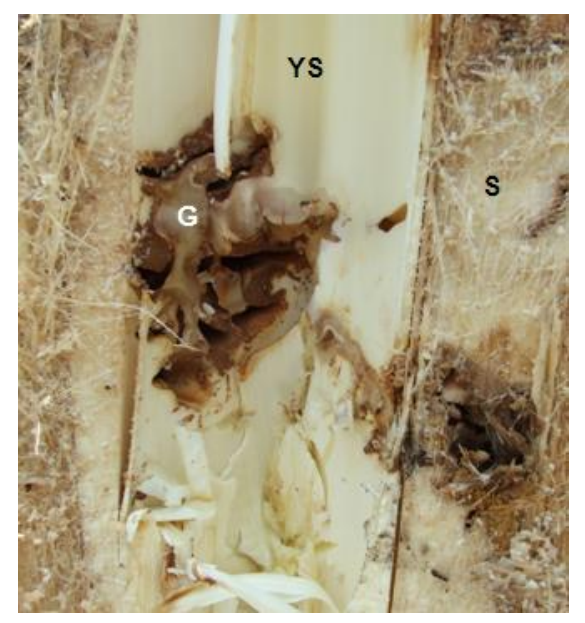

Fig 1: The dissected spear (S) region of the young gallery unopened shoot (YS), where the excavated $(G)$ was found 


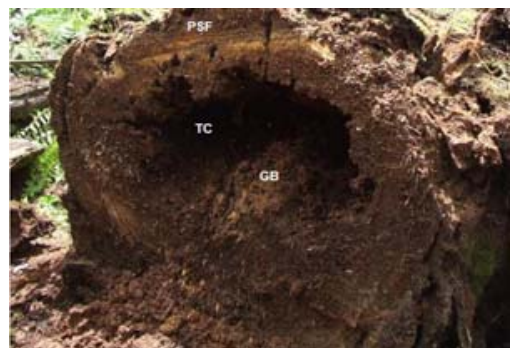

Fig. 2: The Termite Cavity (TC) consumed by surrounded Coptotermes curvignathus in oil palm trunk by the Periphery Supportive Fibrous region (PSF) with the Growth Bulb (GB) intact

However, these subsidiary nest building was not always present unless in seriously infested palm. In most cases, C. curvignathus excavated an ovoid chamber, upon entering the interior of the palm via the spear. Then it continued to construct galleries by excavating in the periphery supportive fibrous phloem region and made a huge cavity in the core of the palm which was filled by the meristem tissue. The size of the cavity made was varied with the age of the palm and the severity of infestation. Similar pattern was observed in palm being attacked from the basal region. As soon as it entered the interior of the palm via the peripheral supportive fibrous phloem region, C. curvignathus excavated an ovoid chamber but in this case surrounding the growing bulb. Massive galleries were excavated in the peripheral supportive region surrounding the cavity and sometimes concave depressions were discovered.

A carton chamber filled with interconnected galleries was then constructed in the depression. The chamber has a wrinkled surface with a smooth base inside the depression (Fig. 3). Soldier and worker castes were found apparently residing in the chamber. The carton material brought in by the termite in gallery construction, together with the chamber construction resulted in radially flattened layers that covered the whole cavity.

At the same time as $C$. curvignathus damaged the palm, it also partially partitioned the ovoid chamber with thin carton laminae in a peripheral contour manner, layer by layer with irregular and elongated cells throughout the chamber which was often described as honeycomb structure, while leaving the centre of the ovoid chamber hollowed. The laminae usually ovoid in shape and when this gallery was cut vertically, elongated and irregular cells would be observed but when sectioning was done perpendicular to the former, diamond shape cells were seen.

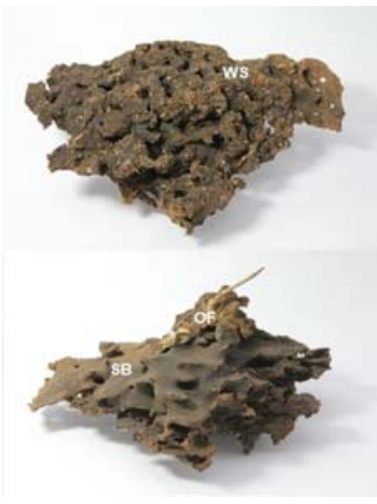

Fig 3: The carton chamber that resided in the concave a depression that has a Wrinkled Surface (WS) and Smooth Base (SB) attached to Oil Palm Fiber (OPF)

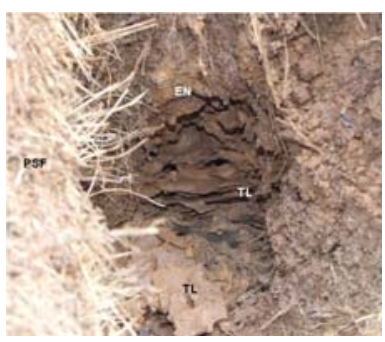

Fig. 4: The dissected section of the oil palm trunk showing the periphery supportive fiber region (PSF) where the endoecie (EN) was contained in an ovoid chamber partitioned with thin lamine (TL)

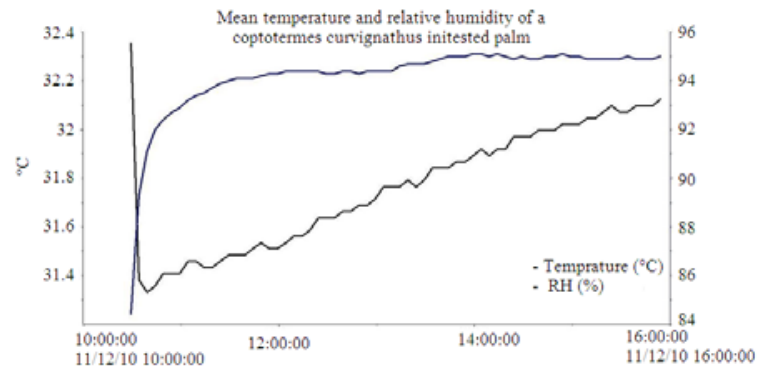

Fig. 5: Mean temperature $\left({ }^{\circ} \mathrm{C}\right)$ and relative humidity (\%) inside the endoecie in oil palm infested by Coptotermes curvignathus

Table 2: Sizes of endoecie with age of palm

\begin{tabular}{ll}
\hline $\begin{array}{l}\text { Age of palm } \\
\text { (years) }\end{array}$ & Size of endoecie \\
\hline 8 & Height $190 \mathrm{~mm}$, width $500 \mathrm{~mm}$ (including the bulb) \\
5 & Height $105 \mathrm{~mm}$, width $210 \mathrm{~mm}$ \\
5 & Height $150 \mathrm{~mm}$, width $180 \mathrm{~mm}$ \\
\hline
\end{tabular}


This also indicated that the partitioning of thin laminae in C. curvignathus was done in a single direction. The ovoid chamber of thin laminae was the endoecie or nursery where nymph and eggs of $C$. curvignathus were found (Fig. 4). The chamber size varied depending on the age of palm since older palms had bigger trunk diameter (Table 2). The nymphs were not found anywhere else other than this area. Lignin analysis revealed that the carton material contained 42$45 \%$ of acid insoluble lignin which indicated a mixture of organic material or concentration of lignin. The temperature in the endoecie within the palm ranged from $31.4-32^{\circ} \mathrm{C}$, while relative humidity was at 94 95\% (Fig. 5).

Damage pattern and nesting characteristic of $C$. curvignathus in a wood stump: In general, the nest building characteristic of $C$. curvignathus in oil palm and wood stump was different in terms of gallery construction (Table 3). Coptotermes curvignathus had been observed to build thin laminae in an excavated cavity outside of the wood stump. This cavity however may vary in size and shape, but the termite would fully partition the chamber with thin laminae which slowly became thicker as it radiated out from the centre (Fig. 6a). Once inside the stump, the termite excavated tunnels directly from the wood to construct galleries using carton material, with no large cavity discovered. The galleries were consistently constructed following the growth ring of the stump rather than focused only in the peripheral supportive region as in oil palm. Galleries formed in wood stump were quite uniform compared to those in oil palm, as layers of thin laminae could be distinguished. The endoecie was similar to a honeycomb structure but the cells were elongated and irregular in sizes and arrangement. The nymphs could be found throughout the thin laminae but the egg mass was only found deep in the stump protected by the thin laminae galleries (Fig. 6b). No reproductive pairs had been spotted in the endoecie.

There were isolated cases where, the stump acted as a protection roof for termite nesting. An ovoid chamber (120 mm in height, $500-650 \mathrm{~mm}$ in width) was first excavated before the partitioning of thin laminae and occurred right under the centre of the stump (Fig. 7). There were 3 runways as large as 90 $\mathrm{mm}$ in diameter protruding out from the endoecie. Each of the runways was filled with galleries made of carton. Soldier and worker caste could be found throughout the runway but the nymph was only found in the endoecie. The thin laminae was built in a layered formation in an ovoid shape with thickness of 1.1-2.3 mm and came in various sizes ranging from $2.9-4.8 \mathrm{~mm}$ in height and 5-6 $\mathrm{mm}$ in width. A primary reproductive queen was found and measured $11 \mathrm{~mm}$ in total length and $1.43 \mathrm{~mm}$ in width of the abdomen, within the endoecie as it did not reside in a queen chamber.

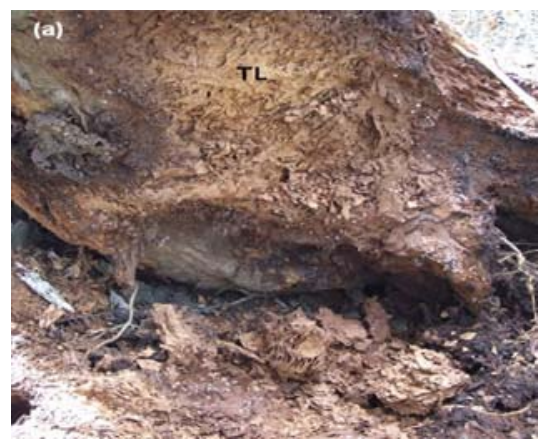

(a)

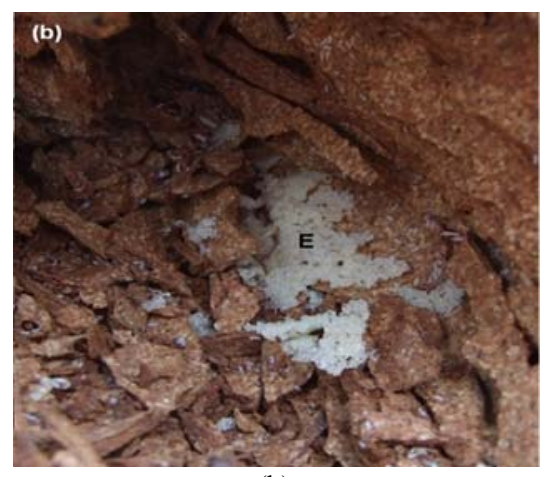

(b)

Fig. 6: (a) The Coptotermes curvignathus infested wood stump with thin laminae (TL) constructed outside and on stump surface (b) The egg mass (E) of the termite was found inside the stump hidden by the laminae

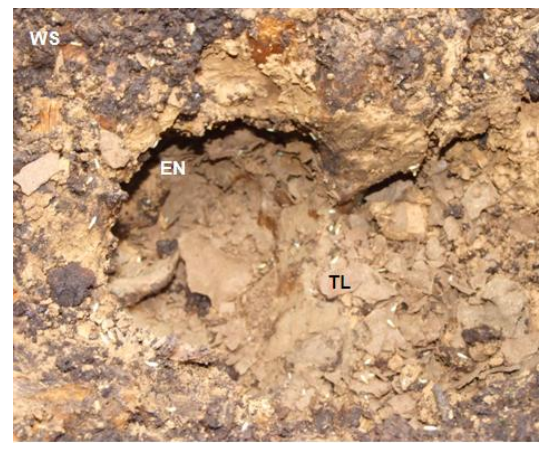

Fig. 7: The opening of the runway where the endoecie (EN) of thin laminae (TL) was found beneath the wood stump (WS) 
Am. J. Applied Sci., 8 (5): 420-427, 2011

Table 3: Characteristic of nest building in oil palm and wood stump

\begin{tabular}{ll}
\hline Nesting building & Characteristics \\
\hline In oil palm & Consisted of an excavated ovoid chamber which partially partitioned by thin laminae \\
& Thin laminae was built in a layered formation and single direction with elongated and irregular ovoid \\
shape & Huge cavities and concave depressions were present due to the unevenness of excavation \\
A radially-flattened carton layer was observed where carton chamber was built in the depression as \\
termite quarters \\
Nymphs were found only in the endoecie \\
Consisted of galleries which thin laminae was excavated from the wood itself with no obvious ovoid \\
shape chamber inside the stump, thin laminae also found outside the stump \\
Thin laminae were fully partitioned outside the stump in a layered formation, cells were elongated, \\
in wood stump & No huge cavity was observed as galleries were made following the growth line of the wood; no mud \\
& was found inside the stump \\
& Egg mass and nymph were found deep inside the stump \\
A primary reproductive queen was found mobile in the endoecie covered by the wood stump
\end{tabular}

\section{DISCUSSION}

The common type of infestation on young palm was through the spear region while basal infestation was usually on mature palm. Apparently, the types of infestation depended on 2 factors which were, the energy required and the level of water table. Hypothetically, lower energy requirement and high level of water table would result in spear region infestation while higher energy requirement and low level of water table would result in basal infestation. Naturally, lesser energy would be required for $C$. curvignathus to reach the crown of an immature palm rather than a mature palm, which would have a trunk of at least $1 \mathrm{~m}$ in height. High water table would restrict $C$. curvignathus to tunnel underneath to reach the basal region, thus forcing it to make mud sheeting on the trunk surface in order to avoid the water table. This phenomenon was observed where during rainy seasons, the infestation of $C$. curvignathus tended to increase. Although mud trails was also seen on mature palm, normally it would not reached the crown as pesticide was applied as soon as the mud sheeting was detected. However, if it was left undisturbed it usually took 3 to 4 weeks to reach the crown from the ground level. When C. curvignathus reached the crown, it needed some time to tunnel into the spear area, till then it harbored the crown area for at least a month. During that time, $C$. curvignathus would build mud sheeting and foraged around the crown encouraged by the suitable microclimate provided by the proximity of fronds. Spear region infestation in mature palm required higher amount of energy and also exposed them to danger of predation, desiccation and pesticide. Therefore, it is logical that basal infestation was preferred in mature palm.

By contrast, basal infestation usually occurred in mature palm when the water table was held constant and wood stump was present. The wood stump may harbor the termite previously before the forest clearing for oil palm planting. Standard practice of keeping the water table at 70-90 $\mathrm{cm}$ from the ground level for oil palm planting and during dry seasons provided $C$. curvignathus with a moist corridor to burrow. Since energy requirement for climbing up a mature palm was great and water table was kept constant, $C$. curvignathus would tunnel beneath the palm and excavated into the inner palm by burrowing through the periphery supportive phloem region. This method offered zero detection and no obvious mud sheeting on the trunk surface, which eventually caused severe damaged such as trunk snapping or felling palm.

The infestation of C. curvignathus in oil palm and wood stumps was closely related to their nesting construction (Lim and Silek, 2001). The difference in nesting construction between wood stump and oil palm was the construction of thin laminae and absence of a large cavity in the former. In oil palm C. curvignathus have a tendency to partition the ovoid chamber with thin laminae for breeding purposes as nymphs and egg mass were discovered only in that particular area. It can be considered as a complex subterranean nest builder since $C$. curvignathus created an ovoid chamber but only partially partition the chamber with thin laminae. More evidence would be needed to solidify the reason of the incomplete partitioning of laminae of the endoecie in oil palm. The endoecie of thin laminae was the only location nymphs were found, however no queen reproduction was found in oil palm yet. Meanwhile as the termite forage inside the palm, it resulted in another cavity which was filled with concave depressions. The concave depression apparently held onto a carton chamber which was believed to be a quarter for worker and soldier to reside while foraging.

The total lignin content of oil palm was about $20.5 \%$. The higher the percentage the stronger the material (Abdul Khalil et al., 2006). The acid insoluble 
lignin found in carton material was twice that of oil palm and this indicated that $C$. curvignathus was able to concentrate the lignin content or used peat soil together with oil palm fiber in nest building for construction purposes. In some instances, utilization of clay had also been observed. The presence of clay in termite nest located in a peat area indicates that $C$. curvignathus was able to bring up clay from subsoil similar to that reported on C. brunneus and C. acinaciformis (Greaves, 1962) for nest construction. The difference in material used in nest construction was caused by the availability in that particular location; if preferred material was not available, the worker termite utilized material in the immediate vicinity.

The temperature within C. curvignathus's endoecie was similar to that in the nest of $C$. acinaciformis which was maintained at $33-38^{\circ} \mathrm{C}$ as reported by Greaves (1964). High temperature was expected in the endoecie, since it was the core of the nest where termite activities was at its peak. The temperature was also affected by the external temperature of the palm where fluctuation was observed. Humidity was an important condition where it was kept constant at all times regardless the external humidity. Constant relative humidity also demonstrated by the termites in Ivory Coast and Nasutitermes exitiosus in Australia (Fyfe and Gay, 1938). Apparently C. curvignathus might have humidity regulatory mechanisms to prevent rapid desiccation during hot weather and hindered condensation during rainy seasons not to mention water from the palm and termite metabolism in order to maintain the consistency.

The characteristic of excavation followed by partitioning with thin laminae was found in oil palm but not in wood stump. Infestation of wood stump began when thin laminae was observed constructed from peat into the stump. Coptotermes curvignathus was not observed to be infesting the wood stump from above either in dry or wet seasons. The reluctance may be due to the aforementioned risk and most importantly the suitable environment provided by the oil palm crown was absence. Once they gained entry, vigorous excavation followed the growth ring of the stump begun and thin laminae galleries were constructed by excavation rather than partitioning. This explained the absence of a cavity and mud difference compared to oil palm. Solid clay and openwork of honey comb was not found between the laminae in this study, contrary to. The egg mass and nymph of $C$. curvignathus was found deep inside the stump, but neither reproductive pair nor their chamber was seen. The formation of the endoecie was similar if not more recognizable than in oil palm (Harris, 1971).

The C. curvignathus nest found underneath a wood stump, highlighted the importance of clean clearing upon the establishment of oil palm plantation on peat. Many reported that the residual wood stump in peat plantation was the primary reason of C. curvignathus infestation (Lim and Silek, 2001; Harris, 1971). The stump protected the endoecie similar to the mound building termite species. The reproductive queen found in the endoecie was mobile and not residing in a chamber and thus explained the elusive occurrence of C. curvignathus queen's in a peat area. The instability of the peat environment caused by the inconsistency of water table forced the queen to be mobile. Pearce (1997) also reported on the instability of a young nest as part of the reason that the queen maybe mobile. Evidently the subterranean termite nested in the wood stump which was more stable and usually above the ground water level. This is not surprised as the wood stump may initially harbor the termite (Lim and Silek, 2001; Pearce, 1997; Harris, 1971; Wood, 1968).

Based on our current study, C. curvignathus was generally available within the wood stump near the infested palm and the drainage area. Removal of the wood stump was deemed as a long term control method that would indirectly suppress the population of termite contrary to findings of Cheng and Gurmit. Clean clearing was meant to reduce the opportunity of a stable breeding place for $C$. curvignathus in peat area rather than killing the queen reproductive, since its supplementary was readily able for the queen replacement (Wood, 1968). Once the possible nesting site of C. curvignathus was discovered, counter measures that capitalized on this behavior could be applied to provide a more effective control. Extra precautionary methods could be focused on the more susceptible locations such as drainage area, area where wood stumps were abundant, formerly infested palms and their surroundings. The plantation management could occasionally control the water table after applying chemical to the infested palm. The termite was subterranean and thus an occasional increase in the water table to the ground level might hinder its progress of wandering to other palms, thereby reducing its infestation rate.

\section{CONCLUSION}

Termite infestation in the plantation was closely related to the wood stumps located near to the drainage where constant moisture and protection was available for termite to breed. Plantation management must be 
vigilant in identifying the earliest symptoms of $C$. curvignathus infestation where curative measured may still save the palm. Inspection of the source of termite in an infested area such as the drainage area and wood stump is important. Clean clearing indirectly reduced the chances of termite breeding and nesting. By targeting the control measures specifically on these areas, termite control may become more effective and sustainable with lesser chemicals used.

\section{ACKNOWLEDGEMENT}

This study was supported by e-Science Fund No. 05-01-04-SF0516 of the Ministry of Science, Technology and Innovations, Malaysia

\section{REFERENCES}

Abdul Khalil, H.P.S., M.S. Alwani and A.K.M. Omar, 2006. Chemical composition, anatomy, lignin distribution and cell wall structure of Malaysian plant waste fibers. Bioresources, 1: 220-232.

Fyfe, R.V. and F.J. Gay, 1938. The humidity of the atmosphere within the mounds of Eutermes exitiosus hill. 1st Edn., H.J. Green, govt. printer, Australia, pp: 22.

Greaves, T., 1962. Studies of foraging galleries and the invasion of living tres bu Coptotermes acinaciformis and C. brunneus (Isoptera). Aust. J. Zool., 10: 630-651. DOI: 10.1071/ZO9620630

Greaves, T., 1964. Temperature studies of termite colonies in living trees. Aus. J. Zool., 12: 250-262. DOI: $10.1071 / \mathrm{ZO} 9640250$

Harris, W.V., 1971. Termites: Their Recognition and Control. 2nd Edn., Longmans, London, ISBN-10: 0582466563, pp: 186.

Hoe, P.K., C.F.J. Bong, K. Jugar and A. Rajan, 2009. Evaluation of Metarhizium anisopliae var. anisopliae (Deuteromycotina: Hyphomycete) Isolates and their Effects on Subterranean Termite Coptotermes curvignathus (Isoptera: Rhinotermitidae). Am. J. Agric. Biol. Sci., 4: 289-297. DOI: 10.3844/ajabssp.2009.289.297
Khoo, K.C., P.A.C. Ooi and C.T. Ho, 1991. Crop Pests and their Management in Malaysia. 1st Edn., Tropical Press, Kuala Lumpur, Malaysia, ISBN-10: 9677300695, pp: 242.

Lim, K.H. and B. Silek, 2001. Termite Infestation On Oil Palms Planted On Deep Peat In Sarawak: Tradewinds experience. Proceedings of the 2001 PIPOC International Palm Oil Congress Agriculture Conference, Aug. 20-22, Kuala Lumpur Malaysia, pp: 365-368.

Pearce, M.J., 1997. Termites: Biology and pest management. 1st Edn., CAB International, ISBN10: 0851991300, pp: 172.

Su, N.Y., P.M. Ban and R.H. Scheffrahn, 2000. Control of Coptotermes havilandi (Isoptera: Rhinotermitidae) with Hexaflumuron Baits and a Sensor Incorporated into a monitoring and baiting program. J. Econ., Entomol., 93: 415-421. DOI: 10.1603/0022-0493-93.2.415

Su, N.Y., P.M. Ban and R.H. Scheffrahn. 1991. Suppression of foraging populations of the formosan subterranean termite (Isoptera: Rhinotermitidae) by field applications of a slowacting toxicant bait. J. Econ., Entomol., 84: 1525-1531.

Thapa, R.S., 1981. Termites of Sabah. 1st Edn., Sabah Forest Department, Sandakan, pp: 374.

Tsunoda, K., H. Matsuoka and T. Yoshimura, 1998. Colony elimination of Reticulitermes speratus (Isoptera: Rhinotermitidae) by bait application and the effect on foraging territory. J. Econ., Entomol., 91: 1383-1386.

Wood, B.J., 1968. Pests of oil palm in Malaysia and their control. 1st Edn., The Incorporated Society of the Planters, Kuala Lumpur, pp: 204. 